Article

\title{
Trolls, Pressure, and Agenda: The Discursive Fight on Twitter in Turkey
}

\author{
Uğur Baloğlu \\ Faculty of Applied Science, Istanbul Gelisim University, Turkey; E-Mail: ubaloglu@gelisim.edu.tr
}

Submitted: 24 February 2021 | Accepted: 23 July 2021 | Published: 21 October 2021

\begin{abstract}
Censorship, banning, and imprisonment are different methods used to suppress dissenting voices in traditional media and have now evolved into a new form with bot and troll accounts in the digital media age in Turkey. Is it possible to construct a bloc with counter-trolls against the escalating political pressure on the media in the post-truth era? Are counter-trolls capable of setting the agenda? This article discusses the possibility of constructing a bloc against the escalating political pressure in Turkey on the media through counter-trolls in the context of communicative rationality. First, it observes the ruling party's troll politics strategy on Twitter, then examines the counter-discourses against political pressure today; thereafter it analyzes the discourse in hashtags on the agenda of the Boğaziçi University protests. Firstly, 18,000 tweets are examined to understand the suppress-communication strategy of the AK Party trolls. Secondly, the agenda-setting capacity of counter-trolls is observed between January 1, 2020, and February 5, 2021, and 18,000 tweets regarding Boğaziçi protests are examined to analyze the communication strategy of the counter-trolls. The study shows that the populist government instrumentalizes communication in social media, and Twitter does not have enough potential for the Gramscian counter-hegemony, but the organized actions and discourses have the potential to create public opinion.
\end{abstract}

\section{Keywords}

agenda; civil society; communication strategy; counter-trolls; populism; trolls; troll politics

\section{Issue}

This article is part of the issue "Media Control Revisited: Challenges, Bottom-Up Resistance and Agency in the Digital Age" edited by Olga Dovbysh (University of Helsinki, Finland) and Esther Somfalvy (Research Centre for East European Studies at the University of Bremen, Germany).

(C) 2021 by the author; licensee Cogitatio (Lisbon, Portugal). This article is licensed under a Creative Commons Attribution 4.0 International License (CC BY).

\section{Introduction}

Today, 4, 5 billion people use the internet on earth, where approximately 7,8 billion people live, and 3,8 billion of these users have social media accounts (Kemp, 2020). This shows us that more than half of the world population is online. When we narrow the perspective and focus on Turkey, we can observe that 54 million of the approximately 83 million people (Turkish Statistical Institute, 2020) have social media accounts and this rate is parallel to developments in the world, namely, about $60 \%$ of the population uses social media (Kemp, 2020). The increasing number of users of social media indicates that our communication practices will be different from the past. As a matter of fact, we have been experiencing a similar change in communication practices of the typographical age that McLuhan mentioned in Gutenberg Galaxy (1963). This also makes us question the relation between one's connection to the reason. Then, in Western notion, men who have the ability to illuminate the darkness as "homo rationalis" (Çiğdem, 2004 , p. 55) turn into "homo irrationalis" in today's post-truth discussions (Fasce, 2020; Levitin, 2017, p. 2; Pinker, 2018, p. 371).

Emphasizing the normativeness of the concept in the post-truth age in which new communication practices are experienced, Mclntyre (2018, p. 6) indicates that truth is subordinated to the political one and thus contextualized within the framework of its own ideological perspective. This period, during which the truth is deformed, describes an environment in which objective (rational) phenomena are abandoned and non-objective (irrational) personal opinions are dominant. As a matter of fact, Keyes (2004) also points out that during this 
period, lying penetrated into new communication practices, making it easier to deceive people. This can cause different problems in the context of interpersonal communication, but it can lead to greater problems in the channels where news circulation is provided on issues of public concern. The information circulated through social media tools is not subject to any editorial process and has not been inspected, which provides a separate dimension to fake news discussions. In addition to its alternative and liberating potential, these platforms, where polarizing and otherizing discourses are easily got into circulation, pave the way for an environment which is suitable for authoritarian-populist politicians (Grinberg et al., 2019). Recent research on fake news on social media platforms (especially Twitter, due to its alternative news media feature; Kwak et al., 2010) that allows a person to hide behind an anonymous identity also supports this (Bovet \& Makse, 2019; Brummette et al., 2018; Recuero \& Gruzd, 2019). So, what kind of actions does the political authority take if it wants to consolidate its power in a media environment where the truth is ambiguous? How does political power respond to the liberating potential of new communication platforms in an environment where traditional media is neutralized in the context of media, politics, and the intricate relationship of capital? Such questions are important for understanding the way right-wing populist political authorities communicate through the media. Media has been one of the most transformed "power" in the single-party government process since 2002 (Çam \& Yüksel, 2015). The transition (flow) of ownership structure to conservative capital which is close to political authority is one of the main indicators of ideological monologism in traditional media (Media Ownership Monitor Turkey, 2019). The colonization of the media by the party, conceptualized by Bajomi-Lázár (2013) through Hungary, points to a similar process in Turkey. During the 2013 Gezi Park protests, the economic and ideological hegemony of the media controlled by political authority was surpassed, and social media was then used as an alternative means of communication. This determines the attitude that the political authority will introduce to social media in the future.

The relationship between power, capital, and the media in Turkey indicates a long-term process. Today, however, as a result of restrictions, bans, and obstructions on freedom of expression, the pressure on the media has augmented. This is confirmed by the World Press Freedom Index of Reporters Without Borders (2020), with Turkey ranked 154th out of 180 countries. Today, political power does not merely use the means of repression, such as prohibition, obstruction, or investigation and imprisonment of journalists (The Journalists' Union of Turkey, 2021); it develops different tools to make media domination invisible and expand the field of discourse. Troll-politics, which describes changing the agenda in the political context, making propaganda, producing disinformation, and/or producing hate speech to suppress opposing/oppositional view, is perhaps the most serious technique in these tools. The fact that social media is a suitable platform for producing userderived content helps the political authority, through trolls, to manipulate people in order to lure them into futile disputes or deviate them from provocatively getting involved in an ongoing discussion. That is to establish both the dominance of its own discourse and to divert opponents from the subject by decontextualizing the discussions (Binark et al., 2015, pp. 127-128). The way such political discussions are held in channels such as Twitter is significant in terms of projecting the image of supporting freedom of expression. This new communicative strategy creates the illusion that propagandist statements, lies, and polarizing discourses circulate through the people, not directly from the political power, causing the truth to be ambiguous. The effort of authoritarianpopulist political authority to create/set its own agenda through trolls by making insignificant the truth or distorting it out of discourse in the post-truth period opens up a space for it to reproduce its hegemony.

Since 2013, AK Party has been actively displaying a policy on social media through its digital office headquarters (Altuntaş, 2015). AK Party's troll army's attempt to put pressure on Twitter is important both to figure out its populist politics and to determine a strategy against it. Since the relationship between the threat of liberal democracies turning towards authoritarianism and the negative trend in the communication paradigm necessitates organized struggle against authority on social media platforms. The article seeks to answer the question of how to create a bloc against the troll policy of political authority in the post-truth age. Besides, it asks if the counter-troll politics have brought the common good rather than polarizing society. The study will first examine the counter discoursive attacks of groups trying to make their voice heard against political authority today after observing AK Party's troll politics strategy via Twitter (Bulut \& Yörük, 2017; Karatas \& Saka, 2017).

\section{Data and Method}

In this research, two different methods were used, namely, content analysis of hashtags and thematic analysis of trolls' tweets. Content analysis is a quantitative approach that summarizes the numerical outputs of variables, whereas thematic analysis is a qualitative method that emphasizes "constellations" by examining the patterns of meaning in texts (Neuendorf, 2019, p. 213). It was observed how long the hashtags remained on the agenda and the number of retweets to reach the most influential content in the data collective section of the study. TAGS v6.1.9.1 and Twitter Search were used to scan all sets of tweets sent by active users. Categories of Stanford Internet Observatory Cyber Policy Center were considered for the detection of troll accounts. The tweets were examined considering the structural features such as the joining date, account name, profile 
information and photo, consistent political tweets, and being an active user (tweeting per day; Fuchs, 2017, p. 54; Grossman et al., 2020). The tweets were selected from the users with the most followers, most retweeted, and likes among 18,000 tweets. Besides, the content of the tweet threads was also checked in accordance with the theme. The network analysis of Hafıza Kolektifi (“'Ak Trol'lerin haritası," 2015) on Twitter demonstrated that Aktrolls, namely, trolls supporting AK Party and AK Party executives were in contact. In the determination of troll accounts, the accounts associated with the political party-related, politicians, and the relationship they establish with their own troll groups were also taken into account in terms of embodying the relationship with the political party (retweeting and/or liking each other's tweets). Based on the information presented in the first analysis, tweets posted in hashtags that were trending at the Boğaziçi University protests-which started with students and academics protesting the appointment of a new rector in a presidential decree-made up the sample group.

First, their posts were divided into themes to analyze the communication strategies of the trolls supporting AK Party. In the case study, the discourses of 18,000 random tweets posted with the hashtag \#DevletiminYanındayım (lamWithMyGovernment) and the tweets of 19 active accounts with the most followers among 18,000 tweets were examined. Since the communication strategies of accounts with trollpolitics contain similar themes, the analysis is limited to 19 accounts. \#Kabekutsalımızdır (KaabalsOurHoly), \#KabeyiSavunanFişleniyor (TheOnesDefendingKaabaAre Blacklisted), and \#ProvokatörlerdenişgalGirişimi (InvasionAttemptByProvokers) hashtags were included in the study because they were thought of as launching flares for the Boğaziçi protests.

In the second analysis, hashtags used by the ones aiming to produce counter-discourse and their capacity to create an agenda, and how many people they reached, were examined. Within the framework of the discourses developed against political power, the selection of hashtags was limited to topics that could reach a minimum of 100,000 tweets and be on the agenda between January 1, 2020, and February 5, 2021. The maximum number of tweets and how long the hashtags remain on the agenda data were found by examining daily Twitter trending data. Then, the "troll-politics" strategy of opposition groups aiming to establish counter-hegemony by producing counter-discourse was examined. The author tried to find out whether the counter-discourses were produced by trolls. Their posts were divided into themes to analyze counter-trolls' communication strategy. In the case study, the discourses of 18,000 random tweets posted with the hashtag \#AşağıBakmayacağız (WeWillNotLookDown) were examined.

Finally, the discourses of the second group and the ability to create an agenda on Twitter were interpreted in the context of communicative rationality and counter- hegemony in response to the data in the first group. The capacity of troll-politics to form a counter-bloc in the context of communicative rationality was discussed within the framework of the analyzed data.

\section{Media, Populism, and Troll Politics}

On July 1, 2020, President Erdogan said, "we want these social media platforms completely shut or controlled after bringing the issue to our parliament" (Erem, 2020, para. 5). Every political authority needs the support and control of the media to reproduce its own rulership. AK Party's policies on the media over the past 18 years show that it has continuously intervened in the media to maintain its own discursive order (Erem, 2020). In order for the political authority to convey its populist policies to the public within the framework of its own reality, it is essential that the media be under its own control. For this reason, the decrease in public consent, especially in times of economic crisis, features the oppressive aspect of the government, as seen in Erdogan's statement (Gramsci, 1971, p. 246). The media policy, which began with the seizure of Star TV (which belongs to Uzan Group) in 2004 as soon as it came to power (Duran, 2015, pp. 20-21), continues with the transfer of the media sector organizations of Doğan Group, which is called the "flagship" of the press, to Demirören Group in 2018. AK Party tries to actualize not only an economic but also an ideological, social, and cultural transformation while creating its own hegemony in the field of media. While the discussions on how successful the government is in this regard continue, a striking point is the polarization of society (Bulut \& Yörük, 2017). The fact that populist politicians try to establish their own discursive dominance by polarizing society is shaped by two different lifestyles created between the public and the elite. The populist identity that stands out as authorized to protect the interests of the people promises to transform the elitist institutions that existed in the past (Aytaç et al., 2021, pp. 5-6). Turkey's modernization process is different from the West. It is crucial to figure out the success of populism today to understand the reactions of the masses that are not represented in the public field in Turkey. The policy is to plan a new path by keeping secularism and Islamic thought in a certain balance policy (Kaya, 2015). Likewise, the ruralization of the urbanites with the migration from the village to the city has progressed faster than the urbanization of the villagers. This has de-eliteized Turkish modernization. Especially after 1950 (after the Democratic party came to power), Turkey began becoming Anatolianized (provincialized; Mardin, 1991, p. 276). The populist politician who shows himself as an anti-elitist and anti-intellectual (Ghergina et al., 2013, p. 3) aims to create the image of a global political leader with their nostalgic bond with the past and heroism anecdotes. At this point, he reproduces his discourses in a populist context, based on the power of the frantic masses, which has been repeatedly excluded from 
the public sphere in the past. The media, on the other hand, uses different methods such as "claim" and "repetition" (Le Bon, 1997, p. 47) to internalize some thoughts and beliefs of the masses and consolidate the power of political authority.

2013 points out a break in Turkish media history. People tend to social media as a result of the unsuccessful portrait of traditional media during the Gezi Park protests. Thus, political reporting reflex develops on social media, especially on Twitter (Karatas \& Saka, 2017, p. 385). In the light of these developments, despite the decentralized nature of social media, the fact that it is an organized communication platform against the power makes AK Party give more importance to online activity. Authoritarian-populist governments, which use similar troll armies as propaganda vehicles in the world, manipulate the public in the context of their ideology with the information they circulate through platforms such as Twitter. Today, the spread of disinformation takes place not through old mass media such as radio and television, but rather with tweets, bots, and fake social media groups (Weedon et al., 2017).

Each period creates its own discourse and concepts. The concept of trolls also indicates a popular concept thanks to new communication technologies. We can get a clearer grasp of troll-politics when we consider that the AK Party has instrumentalized communication practices in order to establish its hegemony and expand its power.

\subsection{Analysis}

Twitter, users of which are increasing day by day and gaining alternative news media features, has become a platform where AK Party institutionalizes political communication negatively in terms of setting, changing or decontextualizing the agenda, polarizing society, spreading propaganda, and producing hate speech (Binark et al., 2015 , p. 128). The accounts and tweets reviewed in the analysis indicate that the discourses that develop against the Boğaziçi protests are categorized within three different themes. The first is the polarizing discourses in which the opposition of "me and the other" is highlighted by referring to nationalist and/or religious elements and identity politics is at the center. Laclau (2005) notes that collective identity and the other positioned in front of it are the main means of understanding populism today. We see a similar political discourse in the tweets of trolls on the "us" and "them" polarization of political power.

As part of the Boğaziçi protests, some students held an exhibition on campus. One of the images in the exhibition was a painting standing on the ground with the Kaaba figure on it. There was a Shahmaran figure (a mythological creature in Anatolia that is believed to bring abundance, wealth, happiness, luck, and protect people from evil eye, has been the subject of legends, with a head in the form of a human and a body in the form of a snake) in the middle of the painting, and LGBTI+, lesbian, trans, and asexual flags were placed at its four corners:
@TheLaikYobaz: Against the cowardly children of Mount Olympus, we are the brave sons of Mount Hira! (SON LAIK BÜKÜCÜ, 2021a, translation by the author)

@KacSaatOlduTR: Why are you silent, Mr. Kemal? Aren't you going to say anything against provocateurs who have threaten promising college students, targeted the Kaaba, represented the people of Lot? Or are you an enemy of religion, too? (Kaç Saat Oldu?, 2021b, translation by the author)

The picture of the Kaaba figure surrounded by LGBTI+ flags at Boğaziçi University was criticized by AK Party supporters for insulting religious values. The picture, described as a derogatory attitude towards sacred values, provided the AK Party with the illegitimate populist way of communicating towards polarization within the framework of religious discourse. As it can be seen in the tweets above, a Muslim/non-Muslim contrast is created by referring to religious elements. In the first tweet, the enmity of Greek mythology and Islam and Greek-Turk are based on religious-nationalist discourse, while the second tweet creates a polarization over religious hostility by targeting the opposition party. In the tweets reviewed, it was observed that the populist communication strategy, in which polarizing discourses are seen commonly within the framework of similar identity politics, was implemented. Within the framework of me-other polarization, "me" points out the people with a statist and Muslim identity, while the "other" represents the people opposed to Islamic values and the government.

The second one is manipulative tweets containing threats, profanity, humiliation, and/or disinformation involving political, social, or direct personalized discourses. Özsoy (2015), who conducted a study on trolls in Turkey, states that trolls generally prefer a provocative, manipulative, and negative language of discourse (p. 537). When the troll-politics accounts were examined, it was found that a similar language of communication prevailed. Aktroll's follows a strategy that constantly emphasizes the distinction between "me and the other" and constantly targets the other, and in this context, re-creates the issue or the agenda within the framework of its own reality. Thus, the subject or agenda is distorted from its own context and tried to be cut off in the abundance of different discussions:

@THEMARGINALE: There you are, we said before. Their problems are neither rector nor university. They're just trying to ignite the fuse of a new attempt. (Marginale, 2021, translation by the author)

@emirbereket: WE DO NOT WANT TERRORISM on the street, in universities, in public, in parliament. (Eemir Bereket, 2021, translation by the author)

In all the videos and images in the hashtags examined in the Boğaziçi protests, protesters are shown in an 
offensive and damaging context. At this point, reality becomes a phenomenon that varies from individuals' point of view. However, this includes the threat of suppressing the voices of opposing views and the danger of preventing democratic participation. That's why, "unlike trolling, troll-politics is serious," as Merrin (2019, p. 291) emphasizes. As it is seen in the above tweets, trolls are trying to manipulate AK Party supporters into believing that the protesters are terrorists by invoking the July 15 coup attempt. Most manipulative tweets consist of offensive discourses directly targeting the opposition wing with negative communication styles such as hate speech and humiliation. Likewise, research on troll culture in Turkey demonstrates that Aktrolls follow a similar communication strategy (Binark et al., 2015, p. 138). In addition to the research findings, it was observed that within a year, the manipulation was created through the posts circulated in a language that was condescending, incriminating, and derogatory especially for Ataturk and Republican People's Party (CHP), and that otherizing language such as \#AtatürkDiktatördür (AtaturklsDictator), \#FetöcüKemal (FetöMemberKemal), \#KemalizmYıkılıyor (KemalizmAreBreakingDown), and RezilsinCHP (DisgracefulCHP) was used intensively.

Thirdly, there are the conspiracy theories frequently used by right-wing populism, often pointing to the ambiguity and popular theories to minimize the consequences of unexpected effects in moments of crisis (Wodak, 2015). Although disinformation and conspiracy theories did not emerge with social media, its circulation became widespread and its quantity augmented. The common point in the analyzed tweets is the emphasis that the protests are led by different enemies. The tweets underline that protests are planned by people or groups that are different from each other but intersect at some points such as Soros, USA, Mason organizations, and Fetö:

@AntepliMamato: The Bogazici was saved from the "Colonial" occupation. -The military was saved from the "Feto" invasion. -The mountains were saved from the "PKK" occupation. -Foreign Affairs was saved from the "Monchère" invasion. -The bureaucracy was saved from the "Mason" occupation. -The industry was saved from the 'Bourgeoisie' occupation. That is because they are going mad. (Mamo Dayı, 2021)

When past network maps of trolls are examined, it shows that they are working organized to silent opponent voices and create a lynching environment in a social media environment (Bulut \& Yörük, 2017; Karatas \& Saka, 2017). It is possible to say that AK Party's own troll army is working more organized and coordinated than they have done in the past. Furthermore, it can be said that it is not only to suppress opponent voices and manipulate them, but also to take the existing agenda out of context and use troll-politics as instruments by changing the direction of the debate. In a year studied, Aktrolls constantly try to respond to counter-trolls with counterattacks. For instance, it always tries to change the trends with populist and accusatory responses like \#geziihanettir (GezilsBetrayal) and \#GeziDarbesi (GeziCoup) after a few hours after hashtag \#GeziyiSavunuyoruz (WeDefend Gezi) was trending, or \#Bismillah, \#ErdoğanınYanındayım (lamWithErdogan), and \#ŞehitlerTepesiBoşDeğil (MartyrsHillIsNotBare) after \#negülüyorsunerdoğan (WhyAreYouLaughingErdogan) hashtag was trending. It is also a remarkable detail in which different troll identities take part in different tasks. While some trolls work only to increase the number of retweets to support the hashtag, some trolls produce conspiracy theories. Trolls, who are also in touch with real users (e.g., @elonue, @zekibahce, and @ERKANTAN__), try to mobilize masses by consolidating the undecided audience.

\section{Democracy, Civil Society and Counter-Troll Politics}

Although the intricate relationship of traditional media with capital and political authority imposes an ideological and technological simplex communication, ideas have been put forward that those social media platforms have evolved towards a participatory, interactive, and collective system and that all these developments strengthen democracy and save it from centralized domination (Hermida, 2010; Jha \& Kodila-Tedika, 2020). Is this practically possible for countries like Turkey that have still not created a culture of democracy (Karpat, 2010, p. 53)? Turkey's transition to democracy was not actualized by the institutionalization of civil society, but by the efforts of the state elites. In other words, democracy in Turkey has not developed due to the lack of a civil society notion-inherited from the Ottoman Empire, where political, economic, and social power was gathered at a single point (Heper, 2000, p. 78). Likewise, when Turkey's struggle for democracy is examined in a historical context, it points out to a process that has been constantly interrupted by forces such as the army and political authority rather than the demands of the people. One of the most important reasons for the inability to institutionalize democracy is that Turkey's industrialization process starts late and a large part of society lives in villages (Kongar, 2001). When this is evaluated within the framework of urbanized/non-urbanized societies, cultural differences between NGO's and religious-ethnic communities can be observed more clearly.

The deep relationship of the culture of liberal democracy with civil society can help us understand today's communication practices (Fukuyama, 1995). In this context, the idea of Habermasian civil social power has the potential to gain its own legitimacy against today's authoritarian power as a communicative power. However, it can be said that this is possible in an organized and systemic way with the idea of a civil society institutionalized by getting rid of the domination of state and political parties as an initiator of the opinion leaders of society as expressed by Göle (2000). Because civil 
society should not be positioned as an over-politicized anti-government directly in the face of political authority. Thus, it contributes to the culture of democracy with civil society, which stands out from the oppression of authoritarian politics and creates an autonomous field for itself. This can only be achieved through "the transition from identity politics to interaction policies" (Göle, 2000, pp. 80-81).

Despite the post-republican Westernization moves in Turkey, the state is positioned as an absolute device of hegemony, where an East-type tradition still brings out itself in political, social, and cultural reflexes because of its connection with the past. In this context, depoliticizing the public sphere does not allow the implementation of a strong interaction policy. Overcoming this situation-in other words, the non-feudalization of the public sphere-can be achieved by the politicization of social life, the rise of citizen journalism, and the struggle for freedom of expression (Habermas, 2013, p. 17). The ideal Habermasian communication environment conceives an environment in which dissident people interact with each other and carry out their own ideas freely, without exclusion and within the framework of the politics of respect. According to Habermas, people/groups in social practices with communicative rationality can achieve common good through collective actions. At this point, communicative action is the dominant element of participatory democracy. By creating an environment where individuals can freely defend their own ideas/arguments in ideal discussion environments, interaction is provided with the exchange of opposing views (Habermas, 2001). Whether Twitter and/or other social media platforms provide such an environment by democratizing communication is still a matter of debate. So, can Twitter allow counter-troll groups to build counter-hegemony in a Gramscian sense? According to Gramsci, hegemony is:

Made possible by the dialectic togetherness of force and consent; accordingly, the ruling class must have ideological and institutional foundations along with material forces in order to achieve the consent it needs beyond a difficult domination and to build its hegemony. (Akgemici, 2019, para. 2)

\subsection{Analysis}

In a study on Twitter, it is found that $73 \%$ of trend topics come up only once, and $31 \%$ stay on the trends for just one day (Kwak et al., 2010, p. 597). When the duration of counter-discourses and the number of retweets are examined as seen in Figure 1, meaningful parallelism is established with the research of Kwak et al.

The remarkable fact of the study's findings is that the country's agenda and the topics that remain on the trends on Twitter for more than a day are partially the same. In total, only four of the 138 issues remain on the trends for more than a day, and only two of them are on the country's agenda, which indicates the political authority's inaction on the demands of the opposition wing. \#CezaevlerindenHaberVar (NewsFromThe Jails) and \#EbruÖlüyorAcilTahliye (EmergencyEvacuation EbrulsDying), headlines led by the Peoples' Democratic Party, are on Twitter trends, but are not on the country's agenda. However, the topics (\#Cocukistismarının AffıOlamaz [ChildAbuselsınexcusable] and \#Aşağı Bakmayacağız [WeWillNotLookDown]) that bring together artists, politicians, ordinary people, and anonymous accounts remain on the agenda. When analyzed, collective movements of artists and different political identities are factors in determining the country's agenda.

When examined in the context of the topic as seen in Figure 2, the contents are clustered within five different themes. In 3\% of the content, hashtags such as \#10Kasım (November10) and \#AtatürküÇokSeviyorum (ILoveAtaturkSoMuch) against populist policies conducted through the people and the elite are carried out to remember republican values. Likewise, femicide is a problem that individuals struggle with, regardless of political ideology. Over a year of review, the most recurring contents have been related to officer appointments. Contents related to officer assignments demonstrate that manipulation of bot accounts may be on the trends in a short period of time. The negative correlation between unemployment and employment in Turkey provides an environment for individuals to develop a pragmatic communication language and make their own problems visible.

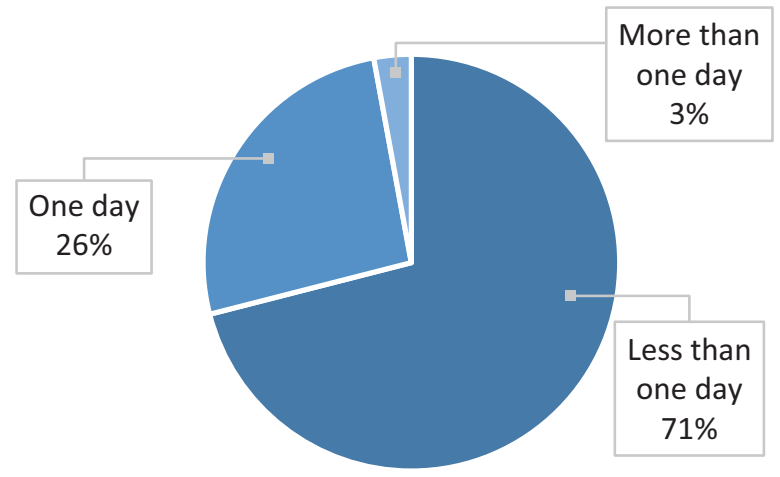

Figure 1. Duration of counter-trends on the agenda. 


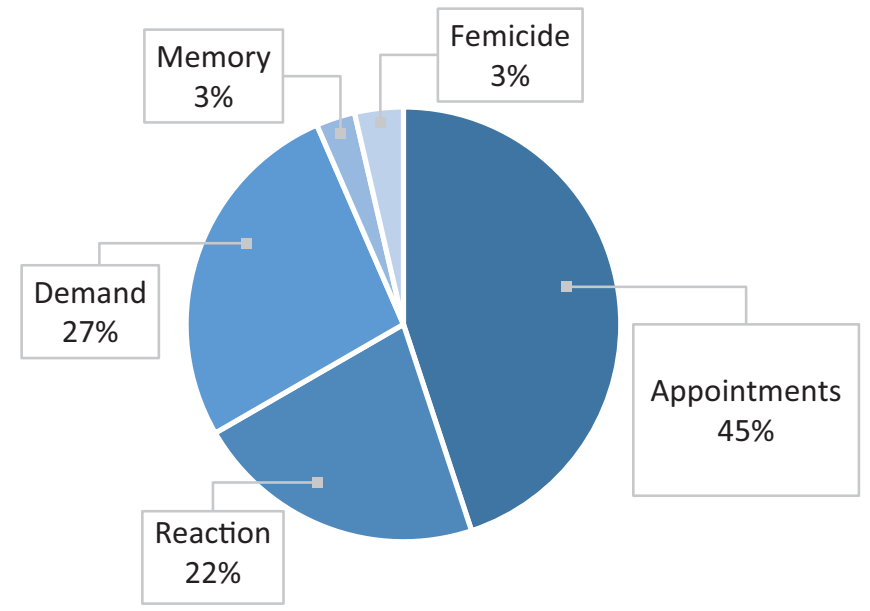

Figure 2. Themes of Twitter counter-trends.

Twenty-seven percent of the analyzed agendas constitute democratic demands from the government. Eleven of the 138 agendas focus on the improvement of sanitary requirements and release of political prisoners in the pandemic; 14 focus on postponing students' exams in the pandemic; and nine focus on improvements in the salary and personal rights of civil servants. These groups use Twitter for pragmatic purposes to attract attention and make their voices heard, even if they are not on the country's agenda. Masses looking for solutions for their own interests instead of achieving common good through communicative rationality turn Twitter into a medium where the populist language is found rather than the Habermasian ideal communication environment. However, this situation is closely related to the non-institutionalization of civil society logic in real social life. As a matter of fact, the individual who cannot be organized in real social life tries to realize his democratic demands indirectly by creating public opinion.

One of the most crucial findings of the study is that there are organized reactions to negative communicative actions of power. "Reaction," which constitutes $22 \%$ of the trends, is the counter-discourse formed by meeting with different segments of society on issues such as unemployment, adverse working conditions, pressure on the opposition media, and reaction to social media restrictions. The discourses and interpersonal communication networks examined indicates that there is a disorganized communication on issues where there are no political parties. It can be said that organized communication usually takes place through the efforts of the Republican People's Party and Peoples' Democratic Party. For example, the posts about the termination of the program attended by Istanbul Mayor Ekrem İmamoğlu on CNN Turk one hour early; and the artist Helin Bölek, who died in a hunger strike in protest of Grup Yorum's concert ban. Besides, after Turkish soldiers were killed in Idlib, counter-trolls develop a nationalist discourse in protest of President Erdogan laughing as he got across a memory of Trump in his speech. One of the common features of the discourses developed directly in response to the government is the use of humor.

In Figure 3, President Erdogan is criticized within the framework of his economic action plan in the pandemic - a campaign called Together We Are Enough My Turkey. In the study, it can be said that the people or groups producing counter-discourse conduct partially a troll-politics strategy. In particular, counter-trollpolitics stand out on issues such as "government resign," which are likely to be politicized and polarized rather than issues that concern the whole society and are sensitive, such as "censorship law" and "child abuse."

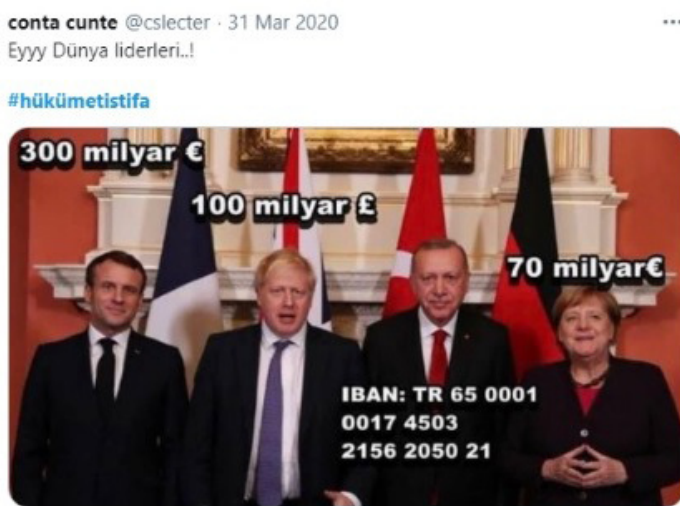

Figure 3. Humorous reaction for measures taken in Turkey against pandemic. Source: conta cunte (2020).

The tweets in the second analysis show that the discourses in the Boğaziçi protests were categorized within five different themes. The structuring of traditional media within the framework of the control of political authority prevents the public from reaching accurate information. In this sense, Twitter becomes a platform where different perspectives and discourses circulate and the public is informed. In the tweets reviewed, detentions, press releases, and police interventions are more likely to be conveyed through various instruments such as writing, photos, and videos. In this sense, most 
content is intended to inform the public in the context of the communication network. For instance, press releases and the protests of Boğaziçi University academics got across to the public without interruption (Boğaziçi Dayanışması, 2021). This can be understood as an effort by counter-trolls to expand the information network on Twitter and create public opinion. The second feature of the tweets that develop counter-discourse is that the discourses are associated with Ataturk in order to preserve the values of the republic against neoOttoman discourses of the government.

The modernization project in Turkey was carried out with the separation from the Ottoman Empire under the leadership of Ataturk. Today, the AK Party is following a policy that wants to transform the founding values and identity of the republic (Ongur, 2015, p. 416). In this context, counter-trolls reflexively protest against AK Party's counter-policy on Ataturk's founding values, often with content that constantly remembers and quotes Ataturk as seen in Figure 4. Thus, a discourse which came up was not only about Boğaziçi University, but also against social transformation and re-identification policies.

Thirdly, it is observed that the content uses a language similar to the manipulative and polarizing discourses used by the Aktrolls. Tweets in which "me and the other" controversy are produced by counter-trolls and often use derogatory and otherizing language have characteristics similar to the populist communication strategy used by political power:

@sigaramcamel: The staffed state of ignorance, you are jealous of the children in schools that you would not be able to enroll even if you made a camel picture with your ass. (Kapheros, 2021, translation by the author)

@MYazar212: Neither can you manage the education! Nor can you manage the health! Nor can you manage the economy! All you can manage are the projects of the partisans. He says, "Whoever has

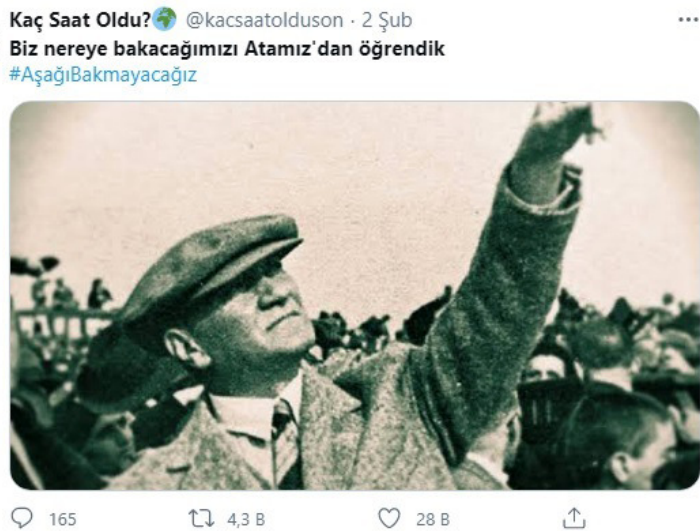

Figure 4. Counter-trolls often refer to Atatürk in quarrels. Note: "We learned where to look from our Father" (translation by the author). Source: Kaç Saat Oldu? (2021a). money crosses my bridge." (MYazar212, 2021, translation by the author)

In general, it is observed that an incriminating and furious language against the economic, societal, and educational policies of political authority is present in such polarizing manipulative tweets. In the examples above that, a language that is condescending to political authority is used.

Another communication strategy used by countertrolls is the humorous discourses on which many studies have been made in the Gezi Park protests. Political humor and intellectual accumulation are considered as a counter-hegemonic strategy developed against the hegemony that the political power is trying to institutionalize (Değer, 2015, p. 319). For example, “@kafayikirdim: Roses are red, Melih is Bulu, He stole an article, And a rectorship, too" (idilos bébé aka. youroti, 2021).

As seen in the example, it is analogically described that Boğaziçi University rector Melih Bulu usurped the office of the rectorship suddenly and unexpectedly with plagiarism accusations in his doctoral thesis. A critical language, similar to Rabelais' Gargantua, was used: "criticism of the corrupted legal system, the traders who defraud the public and those who exploit religious values, with a humoristic but strong language" (Baloğlu, 2019, p. 224). In this context, humorous language is the basis for breaking the wave of fear created by authoritarian policy.

Finally, it is observed that counter-trolls develop ideal discourses that are structured within the framework of "common good," which does not marginalize, polarize, and does not insult. Such discourses contribute to the institutionalization of interactive democracy with the dialogical character of the communicative reason, as well as play an active role in building the common good. Such discourses, in which the ideal state of speech that Habermas speaks of in communicative actions are created, aim at inclusiveness, not exclusion.

Figure 5, indicating that Boğaziçi University students are against any ban, shows that the group described 
as the republican elite also protested against the headscarf ban. In this context, it is underlined that the Boğaziçi protests are not an act developed against pure political authority: “@budirenisi: We repeat that our action is peaceful and repeat our demands!" (Boğaziçi Direnişi, 2021).

These statements of the Boğaziçi Direnişi (Boğaziçi Resistance) indicate that a language is used that pays regard to the public interest, aims at the common good, and does not marginalize. The Boğaziçi Resistance, organized as a non-profit non-governmental organization, tries to convey the extent of the protests directly without falsifying reality by providing continuous information circulation on Twitter.

\section{Discussion and Conclusion}

Based on the research findings, it is seen that AK Party instrumentalizes trolling. This is a maneuver in the political communication of the AK Party. Adopting the concept of majoritarian democracy in real social life, the AK Party aims to create social, religious, and moral pressure on social media by trying to institutionalize the tyranny of the majority with its troll army on Twitter. With the bombardment of information by trolls, the circulation of information becomes excessive and reality becomes ambiguous. In natural disasters like earthquakes, Aktrolls change the trends with hashtags such as \#DevletMilletininYanında (TheGovernmentls WithTheNation). The day after an earthquake, the hashtag \#DevletimizVarOlsun (LongLiveTheState) is brought to the forefront in İzmir. A similar situation is observed in the Boğaziçi protests. The passive resistance, which became the trend against the appointment of rectors with the hashtag \#KabulEtmiyoruzVazgeçmiyoruz (WeDon'tAcceptWeDon'tGiveUp) is drawn into a different context with \#KabeKutsalımızdır (KaabalsOurHoly) counter-attack against the people. The manipulative discourse, that begins with the otherizing and targeting of LGBTI+ individuals, and hate speech are drawn into the context of immorality and devaluation of the sacred value, reflecting the Boğaziçi protests as an act of violence. The most significant point here is that counteractions can be led by manipulations of power. Besides, thoughts/ideas accepted outside the field of hegemonic discourse as if LGBTI+ are prohibited within the framework of freedom of expression. This means that trollpolitics disrupts communicative rationality by targeting people or groups. For instance, although it is claimed that there is freedom of expression, hundreds of people are investigated and imprisoned because of their Twitter posts (“Freedom of expression," 2021).

Troll-politics are more about communicative irrationality than communicative rationality. The reconstruction of the lifeworld depends on strengthening the communicative action. For this purpose, the intersubject mind should be prioritized over the subject-centered (Habermas, 2001). However, the discourses developed by Aktrolls via Twitter are aimed at disrupting the communicative action. Almost all of the tweets have features/characteristics that generate discourses supporting the government, polarize, and disrupt public integrity. Thus, communicative irrationality on Twitter disrupts the type of negotiation-oriented action and supports authoritarian governments to take a hegemonic form. It also marginalizes those who defend fundamental human values - such as human rights, justice, and freedom-and directly accuses the protests of doing terrorist activities. This pushes authoritarianism into a concept legitimized by the people, not by the state apparatus. There is a deep relationship between consenting to authoritarianism and selective exposure to information. On platforms like Twitter, people get the information they want or support in echo chambers (Colleoni et al., 2014). The expression of the envisagement of community formed by people with similar thoughts in the news media results in the reinforcement of the values, beliefs, or opinions held. This becomes a communication style that deepens the opposition of "me and the other," results in more polarization of people and provides the fundamental component of today's populist politics. This indicates a similar process for Aktrolls and counter-trolls because in both groups there is information that will justify their beliefs. For instance, videos circulating in hashtags against the Boğaziçi protests show protesters attacking police (SON LAIK BÜKÜCÜ, 2021b), while videos circulating in the hashtags \#aşağıbakmayacağız (WeWillNotLookDown) and \#boğaziçidireniyor (BogazicilsStandingOut) show police attacking protesters (Zenibya, 2021).

For political authority, the circulatory channels of information are crucial. Media capture (Schiffrin, 2018) not only explains much about the mass communication of authoritarian regimes, but also gives an idea of the rise of right-wing populism and how political power maintains public control. Then, when information circulation is controlled, communication with the public is carried out in the context of ideological monologism. At this point, it is possible to say that hegemony is changing its form with new communication technologies. It is observed that the manufacturing of consent is achieved in new communication technologies without the need for large media companies, but again by acting rationally with trolls. In this context, digital media is more likely to make media capture and can put legal practices in a legitimate order. These findings are in line with what Schiffrin (2018) has summarized as "rather than disrupting media capture, the digital age in some ways appeared only to change how it is manifested" (p. 1036).

The research sometimes reveals short-term trends against political authority such as \#Erdoğandan Korkmuyorum (IAmNotAfraidOfErdogan), \#Hükümet İstifa (GovernmentResign), \#BilaleAnlatırGibi (AsIf ExplainingToBilal), \#MilletNefesAlamıyor (PeopleCanNot Breath), \#yönetemiyorsunuz (YouCanNotGovern), and \#HepBirlikteArtıkYeterDiyoruz (WeSayEnoughAll 
Together), but because it is not sustainable, it cannot reach the majority in a very short time and disappears. This indicates that with too much information and information over-consumption, "passive indifference" has become a cultural norm (Lovink, 2013, p. 6).

Today, Twitter is an area of struggle. This has gained more importance with the conscious and organized practices of political authority, especially after the Gezi Park protests. Although discourse against the political authority is said to have created an agenda via Twitter, in practice, contextual shifts with the performances of government trolls are remarkable. The populist language of communication does not make communicative action possible on Twitter. Thus, the reflexive counter-discourses developed by real people or trolls via Twitter sometimes detract the medium from participatory democracy since it resembles the AK Party's troll army's language of communication. Polarization, the main building block of the AK Party's populist politicswhen troll and counter-troll posts are examined-has become clearer on Twitter. Nevertheless, the communication strategy of the group, which has been marginalized by the AK Party as the country's elite, is closer to the Habermasian politics of respect within the framework of the ethics of public discourse (Habermas, 1990). The majority of the 18,000 tweets categorized within five themes strives to "inform the public," "preserve the values of the republic," and "develop ideal discourses within the framework of the common good." This indicates that counter-discourses are striving to preserve the common good by trying to produce intersubjective consensus in the Boğaziçi protests. Similarly, this attitude of counter-discourses is similar to the Shils' (1991) relationship between civility and civil society because as a feature of civil society, respect takes care of not only the solicitude of the whole society, but also reveals a concern for the establishment of the common good (pp. 11-12). Hence, NGOs in Turkey need to develop a counter-action and communication strategy by being more active and organized. Since plurality and popularity are important on user-derived platforms such as Twitter, it is significant for artists, politicians, and other intellectuals to engage in discussions and for the public to achieve the common good. As observed in the research, discussions that real people do not participate in and do not support remain on the trends for a very short time. Besides, Twitter provides an opportunity to destroy the dominance of the tyranny of the majority created by the intricate relationship between traditional media ownership and political authority. It ensures the creation of public opinion by making protests and people visible, which are made invisible by the captured media. However, excessive information circulation and consumption causes us to ask the question of how organic the resulting public opinion is. How many people remember the Twitter trends-even the country's agenda-examined in the study? The establishment of a counter-hegemonic historical bloc stipulates an eco- nomic, ideological, and institutional organization, not just a discursive struggle. Counter-trolls' ability to form a new bloc against the hegemony of political authority depends on the existence of non-governmental organizations focused on communicative action, autonomous and strongly funded. As a result, the findings demonstrate that Twitter does not have sufficient potential for the establishment of the neo-Gramscian counterhegemony, but there is also the potential for the communicative action taken by counter-trolls within the framework of peaceful actions and discourses to create public opinion (Konda, 2021) and mobilize the majority as in the Gezi Park protests.

\section{Conflict of Interests}

The author declares no conflict of interests.

\section{References}

Akgemici, E. (2019, February 7). Venezuela'da karşıhegemonya: Yenilmeye mahkûm bir mücadele mi? [Counter-hegemony in Venezuela: A struggle doomed to defeat?]. Birikim. https://birikimdergisi. com/guncel/9341/venezuelada-karsi-hegemonyayenilmeye-mahkum-bir-mucadele-mi

'Ak trol'lerin haritası çıkarıldı: Merkezde Erdoğan'ın danışmanı Varank var [Aktrolls' map has been drawn out: Erdogan's advisor Varank is at the center]. (2015, October 14). Diken. https://www.diken.com.tr/aktrollerin-haritasi-cikarildi-merkezde-erdoganindanismani-varank-var

Altuntaş, Ö. (2015, May 18). AKP sosyal medya merkezi'nde bir gün [A day at the social media center of AK Party]. BBC News. https://www.bbc.com/ turkce/haberler/2015/05/150515_akp_sosyal_ medya

Aytaç, S., Çarkoğlu, A., \& Elçi, E. (2021). Partisanship, elite messages, and support for populism in power. European Political Science Review, 13(1), 23-39.

Bajomi-Lázár, P. (2013). The party colonisation of the media: The case of Hungary. East European Politics and Societies, 27(1), 69-89.

Baloğlu, U. (2019). Televizyon dizilerinde komedinin araçsallaşması: etik sınırların muğlaklaşarak toplumsal cinsiyetin yeniden üretimi [The instrumentalization of comedy in television series: Reproduction of gender by ambiguating of ethical boundaries]. In Z. B. Şahin (Ed.), Illetişim Etiği: Kavramlar, Olgular ve Tartışmalar [Communication ethics: Concepts, facts and debates] (pp. 221-258). Literatürk.

Binark, F. M., Karataş, Ş., Çomu, T., \& Koca, E. (2015). Türkiye'de Twitter'da trol kültürü [Troll culture on Twitter in Turkey]. Toplum Ve Bilim, 135, 124-157.

Boğaziçi Dayanışması. [@boundayanisma]. (2021, February 12). Direnişimizin 40. Günü, hocalarımızın basın açıklaması [40th day of our resistance, press release of our teachers] [Tweet]. Twitter. https://twitter. 
com/boundayanisma/status/1360178953206571012

Boğaziçi Direnişi. [@budirenisi]. (2021, February 1). Eylemimizin barış̧ıl olduğunu tekrarlayıp taleplerimizi yineliyoruz! [We reiterate that our protest is peaceful, we reiterate our demands!] [Tweet]. Twitter. https://twitter.com/budirenisi/status/13562845907 68467970

Bovet, A., \& Makse, H. A. (2019). Influence of fake news in Twitter during the 2016 US presidential election. Nature Communications, 10(1), 1-14.

Brummette, J., DiStaso, M., Vafeiadis, M., \& Messner, M. (2018). Read all about it: The politicization of "fake news" on Twitter. Journalism \& Mass Communication Quarterly, 95(2), 497-517.

Bulut, E., \& Yörük, E. (2017). Mediatized populisms/digital populism: Trolls and political polarization of Twitter in Turkey. International Journal of Communication, 11, 4093-4117.

Çam, A., \& Yüksel, i. Ş. (2015). Türkiye'de medyanın 2002 sonrası dönüşümü: Ekonomi politik bir yaklaşım [The transformation of the media in Turkey after 2002: A political economy approach]. In U. Aydın (Ed.), Neoliberal Muhafazakâr Medya [Neoliberal conservative media] (pp. 66-103). Ayrıntı.

Çiğdem, A. (2004). Bir imkân olarak modernite: Weber ve Habermas [Modernity as an opportunity: Weber and Habermas]. İletişim

Colleoni, E., Rozza, A., \& Arvidsson, A. (2014). Echo chamber or public sphere? Predicting political orientation and measuring political homophily in Twitter using big data. Journal of Communication, 64(2), 317-332.

conta cunte. [@cslecter]. (2020, March 31). Eyyy Dünya liderleri..! [Heeeey World leaders..!] [Tweet]. Twitter. https://twitter.com/cslecter/status/124505566022 9832707

Değer, O. (2015). Entelektüel itaatsizlik ve politik mizah: Gezi direnişi [Intellectual disobedience and political humor: Gezi resistance]. Mülkiye Dergisi, 39(2), 319-326.

Duran, R. (2015). Dümdüz....Sessiz....Hareketsiz....Ulvî.... Gibi....Medya nasıl kürtaj edilir? [Straight....Quiet.... Stable....Like.....Divine.... How to abort media?] In U. Aydın (Ed.), Neoliberal Muhafazakâr Medya [Neoliberal conservative media] (pp. 19-30). Ayrıntı.

Eemir Bereket. [@emirbereket]. (2021, February 2). Sokakta, üniversitelerde, kamuda, mecliste TERÖRIST ISTEMIYORUZ [WE DO NOT WANT TERRORISM On the street, in universities, in public, in parliament] [Tweet]. Twitter. https://twitter.com/emirbereket/ status/1356660202624409602

Erem, O. (2020, July 2). Sosyal medya yasası: Türkiye'de bugüne kadar hangi siteler ve sosyal medya platformları yasaklandı? [Social media law: Which sites and social media platforms have been banned in Turkey so far?]. BBC News. https://www.bbc.com/turkce/ haberler-turkiye-53259839

Fasce, A. (2020). The upsurge of irrationality: Pseudoscience, denialism, and post-truth. Disputatio: Philo- sophical Research Bulletin, 9(13), 1-22.

Freedom of expression and the press in Turkey281. (2021, February 13). Expression Interrupted. https://www.expressioninterrupted.com/freedomof-expression-and-the-press-in-turkey-281

Fuchs, C. (2017). Donald Trump: A critical theory perspective on authoritarian capitalism. TripleC: Communication, Capitalism \& Critique, 15(1), 1-72.

Fukuyama, F. (1995). Democracy's future: The primacy of culture. Journal of Democracy, 6(1), 7-14.

Ghergina, S., Mişcoiu, S., \& Soare, S. (Eds.). (2013). Contemporary populism: A contoversial concept and its diverse forms. Cambridge Scholars.

Göle, N. (2000). Melez desenler [Hybrid patterns]. Metis. Gramsci, A. (1971). Selections from the prison notebooks of Antonio Gramsci. International Publishers.

Grinberg, N., Joseph, K., Friedland, L., Swire-Thompson, B., \& Lazer, D. (2019). Fake news on Twitter during the 2016 US presidential election. Science, 363(6425), 374-378.

Grossman, S., Akis, F. A., Alemdaroğlu, A., Goldstein, J. A., \& Jonsson, K. (2020). Political retweet rings and compromised accounts: A Twitter influence operation linked to the youth wing of Turkey's ruling party. Stanford Internet Observatory.

Habermas, J. (1990). Moral consciousness and communicative action. MIT Press.

Habermas, J. (2001). iletişimsel eylem kuramı [The theory of communicative action]. Kabalcı.

Habermas, J. (2013). Kamusallığın yapısal dönüşümü [The structural transformation of the public sphere]. iletişim.

Heper, M. (2000). The Ottoman legacy and Turkish politics. Journal of International Affairs, 54(1), 63-82.

Hermida, A. (2010). From TV to Twitter: How ambient news became ambient journalism. Media/Culture Journal, 13(2). https://doi.org/10.5204/mcj.220

idilos bébé aka. youroti. [@kafayikirdim]. (2021, February 2). Roses are red Melih is Bulu he stole an article and a rektörlük, too [Tweet]. Twitter. https://twitter.com/kafayikirdim/status/1356703778 959941636

Jha, C. K., \& Kodila-Tedika, O. (2020). Does social media promote democracy? Some empirical evidence. Journal of Policy Modeling, 42(2), 271-290.

Kaç Saat Oldu? [@KacSaatOlduTR]. (2021a, February 2). Biz nereye bakacağımızı Atamız'dan öğrendik [We learned where to look from our Father] [Tweet]. Twitter. https://twitter.com/kacsaatolduson/status/ 1356372772780466180

Kaç Saat Oldu? [@KacSaatOlduTR]. (2021b, February 1). Niye susuyorsun BayKemal? [Why are you silent, Mr. Kemal?] [Tweet]. Twitter. https://twitter.com/ KacSaatOlduTR/status/1356003772925931523

Kapheros. [@sigaramcamel]. (2021, February 2). Cehaletin kadrolaşmış hali, götünüzle deve izi yapsanız giremeyeceğiniz okullardaki çocukları aşağılık bir eziklikle kıskanıyorsunuz [The staffed state of 
ignorance, you are jealous of the children in schools that you would not be able to enroll even if you made a camel picture with your ass] [Tweet]. Twitter. https://twitter.com/sigaramcamel/status/13566541 88571340805

Karatas, D., \& Saka, E. (2017). Online political trolling in the context of post-Gezi social media in Turkey. International Journal of Digital Television, 8(3), 383-401.

Karpat, K. H. (2010). Türk demokrasi tarihi: Sosyal, ekonomik, kültürel temeller [History of Turkish democracy: Social, economic, cultural foundations]. Timas.

Kaya, M. (2015). The modernization of Turkey as an example of non-Western modernization: Continuities, ruptures, and diversifications. Turkish Studies, 10(2), 545-564.

Kemp, S. (2020). Digital 2020: Global digital overview. Global Digital Insights. https://datareportal.com/ reports/digital-2020-global-digital-overview

Keyes, R. (2004). The post-truth era: Dishonesty and deception in contemporary life. Macmillan.

Konda. (2021). Toplumun Boğaziçi Üniversitesi olaylarına bakışı [The perspective of the society on Boğaziçi University protests]. https://konda.com.tr/tr/rapor/ toplumun-bogazici-universitesi-olaylarina-bakisi

Kongar, E. (2001). Demokrasi kültürü sorunları [The problems of democracy culture]. Emre Kongar'in Resmi internet Sitesi. https://www.kongar.org/makaleler/ Demokrasi_Sorunlari.php

Kwak, H., Lee, C., Park, H., \& Moon, S. (2010). What is Twitter, a social network or a news media? In M. Rappa \& P. Jones (Eds.), WWW'10: Proceedings of the 19th international conference on World wide web (pp. 591-600). ACM. https://dl.acm.org/doi/ $10.1145 / 1772690.1772751$

Laclau, E. (2005). On populist reason. Verso.

Le Bon, G. (1997). Kitlelerin psikolojisi [Psychology of crowds]. Hayat.

Levitin, D. J. (2017). Weaponized lies: How to think critically in the post-truth era. Penguin.

Lovink, G. (2013). After the social media hype: Dealing with information overload. e-flux Journal, 45. https://www.e-flux.com/journal/45/60109/afterthe-social-media-hype-dealing-with-informationoverload

Mamo Dayı. [@AntepliMamato]. (2021, February 2). -Boğaziçi "Sömürgeci" işgalinden kurtarıldı. -Askeriye "Fetö" işgalinden kurtarıldı [The Boğaziçi was saved from the "Colonial" occupation. -The military was saved from the "Feto" invasion] [Tweet]. Twitter. https://twitter.com/AntepliMamato/status/1356516 973308477441

Mardin, Ş. (1991). Türk modernleşmesi [Turkish modernization] (Vol. 4). Illetişim.

Marginale. [@THEMARGINALE]. (2021, February 1). Alın işte demiştik. Dertleri ne rektör, ne de üniversite [There you are, we said before. Their problems are neither rector nor university] [Tweet]. Twitter.
https://twitter.com/THEMARGINALE/status/135633 8072426848257

McIntyre, L. (2018). Post-truth. MIT Press.

McLuhan, M. (1963). The Gutenberg galaxy. University of Toronto.

Media Ownership Monitor Turkey. (2019). Media \& owners database. https://turkey.mom-rsf.org/en

Merrin, W. (2019). President troll: Trump, 4chan, and memetic warfare. In C. Happer, A. Hoskins, \& W. Merrin (Eds.), Trump's media war (pp. 201-226). Macmillan.

MYazar212. [@MYazar212]. (2021, February 1). Ne eğitimi yönetebiliyorsunuz..! Ne sağlığı yönetebiliyorsunuz..! [Neither can you manage the education! Nor can you manage the health...!] [Tweet]. Twitter. https://twitter.com/MYazar212/status/1356311515 666780160

Neuendorf, K. A. (2019). Content analysis and thematic analysis. In P. Brough (Ed.), Research methods for applied psychologists: Design, analysis, and reporting (pp. 211-223). Routledge.

Ongur, H. O. (2015). Identifying Ottomanisms: The discursive evolution of Ottoman pasts in the Turkish presents. Middle Eastern Studies, 51(3), 416-432.

Özsoy, D. (2015). Tweeting political fear: Trolls in Turkey. Journal of History School, 12(22), 535-552.

Pinker, S. (2018). Enlightenment now: The case for reason, science, humanism, and progress. Penguin.

Recuero, R., \& Gruzd, A. (2019). Cascatas de fake news políticas: Um estudo de caso no Twitter. Galáxia, 41, 31-47.

Reporters Without Borders. (2020). World press freedom index of reporters without borders. https://rsf.org/ en/taxonomy/term/145

Schiffrin, A. (2018). Introduction to special issue on media capture. Journalism, 19(8), 1033-1042.

Shils, E. (1991). The virtue of civil society. Government and opposition, 26(1), 3-20.

SON LAiK BÜKÜCÜ. [@TheLaikYobaz]. (2021a, February 1). Olimpos dağının korkak çocuklarına karşı, Hira Dağının cesur evlatlarıyız! [Against the cowardly children of Mount Olympus, we are the brave sons of Mount Hira!] [Tweet]. Twitter. https://twitter.com/ TheLaikYobaz/status/1355989064663658498

SON LAik BÜKÜCÜ. [@TheLaikYobaz]. (2021b, February 2). Kadıköy'de teröristler tarafından polise karşı barikat kuruluyor [A barricade is erected by terrorists against the police in Kadıköy] [Tweet]. Twitter. https://twitter.com/TheLaikYobaz/status/ 1356661682609733634

The Journalists' Union of Turkey. (2021). 67 journalists jailed in Turkey. https://tgs.org.tr/arrested-jailedjournalists-turkey

Turkish Statistical Institute. (2020). The results of address based population registration system. https:// turkstatweb.tuik.gov.tr/PreTablo.do?alt_id=1059

Weedon, J., Nuland, W., \& Stamos, A. (2017, April 27). Information operations and Facebook. [Press 
Release]. https://www.mm.dk/wp-content/uploads/ 2017/05/facebook-and-information-operationsv1.pdf

Wodak, R. (2015). The politics of fear: What right-wing populist discourses mean. SAGE.

Yakut. [@Maesteroid]. (2021, February 2). Boğaziçi öğrencileri üniversitelerde başörtüsü yasağını böyle protesto etmişti [Boğaziçi students protested the headscarf ban in universities] [Tweet]. Twitter.
https://twitter.com/Maesteroid/status/1356530483 807588352

Zenibya. [@bensuse_]. (2021, February 2). BU VAHŞET GÖRÜLSÜN. KIMSE GÖZÜNÜ KAPAMASIN. KIMSE SUSKUN KALMASIN [THIS VIOLENCE SHOULD BE NOTICED. NO ONE SHOULD IGNORE IT. NO ONE SHOULD BE SILENT] [Tweet]. Twitter. https://twitter. com/bensuse_/status/1356642979985948680

\section{About the Author}

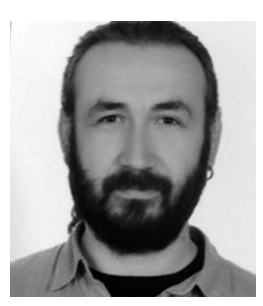

Uğur Baloğlu is an assistant professor in the Faculty of Applied Sciences at Istanbul Gelişim University. He completed his MA in 2012 in the field of communication design at Istanbul Kültür University. He completed his PhD in radio, tv, and cinema at Istanbul University in 2017. He is the co-editor of Transcultural Images in Hollywood Cinema: Debates on Migration, Identity, and Finance (2021). His research interests include media, cultural studies, and communication research. 